Original Article

\title{
Effect of protein and lipids levels in a growth diet on adult whitebait Galaxias maculatus (Jenyns 1842)
}

\author{
Efeito dos níveis de proteína e lipídio em uma dieta de crescimento em whitebait \\ Galaxias maculatus adulto (Jenyns 1842)
}

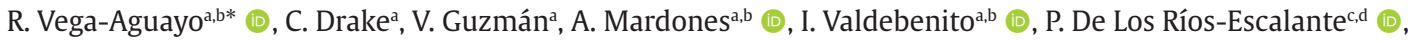 \\ F. Encina-Montoya ${ }^{\mathrm{c}, \mathrm{d}}$ (1) and J. Barile ${ }^{\mathrm{a}}$ (1) \\ aUniversidad Católica de Temuco - UCT, Departamento de Cs. Agropecuarias y Acuícolas, Temuco, Chile \\ bUniversidad Católica de Temuco - UCT, Núcleo de Investigación de Producción Alimentaria, Temuco, Chile \\ 'Universidad Católica de Temuco - UCT, Facultad de Recursos Naturales, Departamento de Ciencias Ambientales, Temuco, Chile \\ dUniversidad Católica de Temuco - UCT, Núcleo de Investigación de Estudios Ambientales, Temuco, Chile
}

\begin{abstract}
Galaxias maculatus aquaculture objectives is to produce millions of eggs. Wild females are small ( $2 \mathrm{~g})$, have quick sexual maturity and low mean fecundity (500 eggs/female), requiring larger fishes with higher fecundity. This study aim is to evaluate experimentally the effect of the levels of protein, lipid and dietary energy on weight increases in adults. Five independent experiments were performed at different sequential time periods at the UCT hatchery, Chile. Specimens were obtained from a) Crystalline sea return specimen catches in the Tolten estuary $(4-6 \mathrm{~cm}$, 0.3-0.4 g.). b) Hatchery cultured fish. Fish were fed by hand ad libitum. In experiments 1 to 4 , pelleted diets were prepared with 3 to 5 levels of protein (treatments 27 up to 57\%), crumble size, three $100 \mathrm{~L}$ fibre ponds replicates. In experiment 5 the effect of two lipid levels ( 8 and 21\%) was evaluated with commercial extruded Salmon Nutra Starter isoproteic crumble 1 diet at $63 \%$, replicated in 4 ponds. The results show: A tendency to increased weight in all sizes with an increased protein level in the pelleted diet.A maximal adult growth is obtained with a diet containing a minimum of $37 \%$ crude protein, with $40 \%$ the optimal value. A higher \% protein in the diet or growth in weight lower feed conversion ratio. The feed conversion ratio in the extruded diet reaches up to 0.5 and in the pelleted vary from 0.7 to 1.5 . Fish $0.6 \mathrm{~g}$ fed with $63 \%$ protein, extruded commercial diet with two different lipid levels ( 8 and 21\%, 20.40 and $23.84 \mathrm{MJ} \mathrm{kg}^{-1}$, PE/TE 0.62 and 0.71 ) increased weight the first month 67 and $105 \%$ each. It has been established that high-energy diets with optimal levels of protein and lipid are a good short-term solution to obtain G. maculatus of higher weight.
\end{abstract}

Keywords: Galaxias maculatus, protein diet, lipid diet, growth.

\begin{abstract}
Resumo
O objetivo da aquicultura de Galaxias maculatus é produzir milhões de ovos. As fêmeas selvagens são pequenas ( $2 \mathrm{~g})$ e têm maturidade sexual rápida e fecundidade média baixa (500 ovos/fêmea), necessitando de peixes maiores e com fecundidade superior. O objetivo deste estudo é avaliar experimentalmente o efeito dos níveis de proteínas, lipídios e energia da dieta sobre o aumento de peso em adultos. Cinco experimentos independentes foram realizados em diferentes períodos sequenciais de tempo no incubatório UCT, Chile. Os espécimes foram obtidos a partir de: a) capturas de espécimes de retorno do mar cristalino no estuário de Tolten (4-6 cm, 0,3-0,4 g); b) peixes de cultura em incubatório. Os peixes foram alimentados à mão ad libitum. Nos experimentos de $1 \mathrm{a} 4$, dietas peletizadas foram preparadas com três a cinco níveis de proteína (tratamentos 27 a 57\%), tamanho do crumble, três repetições de tanques de fibra de 100 L. No experimento 5, o efeito de dois níveis de lipídios ( 8 e 21\%) foi avaliado com dieta comercial isoproteica crumble 1 de Salmon Nutra Starter extrusada a 63\%, replicada em quatro tanques. Os resultados mostram: uma tendência ao aumento de peso em todos os tamanhos, com um aumento do nível de proteína na dieta peletizada; um crescimento adulto máximo com uma dieta contendo um mínimo de $37 \%$ de proteína bruta, com $40 \%$ do valor ideal; uma porcentagem maior de proteína na dieta ou crescimento em peso com menor taxa de conversão alimentar. A taxa de conversão alimentar na dieta extrusada chega a 0,5 , e na peletizada varia de 0,7 a 1,5. Peixes de $0,6 \mathrm{~g}$ alimentados com $63 \%$ de proteína e dieta comercial extrusada com dois níveis lipídicos diferentes ( 8 e 21\%; 20,40 e 23,84 MJ kg-1; PE / TE 0,62 e 0,71) aumentaram de peso no primeiro mês em 67 e $105 \%$ cada, respectivamente. Foi estabelecido que dietas de alta energia com níveis ótimos de proteínas e lipídios são uma boa solução de curto prazo para obter G. maculatus de peso mais alto.
\end{abstract}

Palavras-chave: Galaxias maculatus, dieta proteica, dieta lipídica, crescimento.

*e-mail: rvega@uct.cl

Received: May 18, 2021 - Accepted: July 2, 2021

This is an Open Access article distributed under the terms of the Creative Commons Attribution License, which permits unrestricted use, distribution, and reproduction in any medium, provided the original work is properly cited. 


\section{Introduction}

One of the primary challenges and targets of Galaxias maculatus (Jenyns, 1842) culture or "galaxy culture" is to produce millions of eggs, since 3,000 fingerlings per kilogram of product are required. Therefore, during their six month immature phase, maximum weight and maturity must be reached, so that the fish will mature and spawn periodically. Wild females are small (1 to $5 \mathrm{~g}$ ), quickly mature sexually over one year and of low fecundity (500 eggs/female). In experimental cultures, heavier specimens with higher fecundity were obtained (5,000 to 10,000 eggs/ female) when required (Mitchell, 1989; Barile et al., 2003, Mardones et al., 2008). Barile et al. (2003) notes that with increasing female weight, the number of eggs increases according to the equation: Number eggs $=305.5 \mathrm{~W}^{1,0712}$. Therefore, the challenge is to obtain heavier females. The formulation of energy-rich diets with optimal levels of proteins and lipids constitutes a solution to obtain higher weights and fecundity in G. maculatus females in the short term.

G. maculatus is a carnivorous fish. The larvae feed on zooplankton and the adults on arthropods and other benthic organisms. To cultivate breeders in experimental stages, semi-intensive systems are used, based on natural feeding complemented with salmon-extruded food, which generates a quick growth in weight and size, resulting in a higher female fecundity and therefore an increased production of eggs (Vega et al., 2013).

Nutrition has an appreciable effect on gonad activity, increasing growth and fish fecundity (Bromage, 1995) and affecting several reproductive aspects such as time to sexual maturity; fertility, size and quality of the egg, assessed by their chemical composition; and larval survival (De Silva and Anderson, 1995). Therefore, special attention has been devoted to the dietary components, with protein one of the most important because it is one of the most abundant in the eggs of many species (Watanabe et al., 1985).

One of the most important energy sources for fish is proteins, especially in carnivorous fishes, who have a strong dependence on a high protein diet component, because of their ability to digest and metabolize protein compared to carbohydrates (Cowey and Sargent, 1979; Tacon and Cowey, 1985; Cho and Kaushik, 1990; Cho, 1992; NRC, 2011). In high quality fishmeal, protein is the main ingredient in the cultured carnivorous fish diet, as it affects consumption, digestibility and growth (Aksnes, 1995; Aksnes et al., 1997; Vergara et al., 1999).

The optimization of dietary protein use is associated with an improved feed efficiency (Shapawi et al., 2014; Jiang et al., 2016; Wang et al., 2016). Because proteins are increasingly expensive, lipid levels have increased in fish feed production, used as an energy source to save protein and improve the feed conversion ratios. The main effect of these savings in dietary lipids (sparing effect) is to replace a fraction of the protein that otherwise would be catabolized and used as an energy source or to synthesize lipids (Vergara et al., 1996a; Company et al., 1999). Other approaches optimize the use of protein minimum levels in the diet, either for maximum growth in various species of farmed fish (Vergara et al., 1996b; Pérez et al., 1997;
Schuchardt et al., 2008) or as energy in respect to the total diet energy (Santinha et al., 1999; Skalli et al., 2004; Jiang et al., 2016).

The increase in lipids to between 20 to $30 \%$ in fish diets has led to an increase in gross energy up to 22 to 25 MJ kg-1 (Vergara et al., 1999; Peres and Oliva Teles, 1999; Boujard et al., 2004; García-Meilan et al., 2016). This is possible only by the diet extrusion technique, a process that improves the digestibility of proteins, lipids and carbohydrates, promoting a better growth than pelleted diets (Deguara, 1997; Pérez et al., 1997). Carbohydrates, due to their relative digestibility in carnivorous fishes, bind and increase the palatability and flavour of the food (Jeong et al., 1991).

Artificial feeding studies in G. maculatus future breeders are just beginning and are essential to establish the optimal dietary levels of protein and lipid for maximum growth in weight and fecundity. The aim of this study is to evaluate the effect of protein, lipids and energy in pelleted and extruded diets on adult growth in G. maculatus.

\section{Materials and Methods}

\subsection{Diets and experimental design}

To evaluate the effect of protein, lipid and energy in the diets on diadromic adult weight in G. maculatus (Jenyns, 1842), five independent experiments were performed at different sequential periods of time at the School of Aquaculture, Universidad Catolica de Temuco hatchery, Araucania Region, Chile. Four evaluated the effect of protein and energy levels in the diet and the fifth evaluated the effect of lipid and energy levels in the diet. The characteristics of the fish (numbers of ponds and fish, origin: wild or farmed, start weight range and month of experiment duration) are shown in Table 1 . The experiments were repeated, except for experiment 1 , due to fish maturation and mortality. The experiments are labelled as 2.1 (the first) and 2.2 (its repeat), for example.

Specimens were obtained from a) Crystalline sea return specimen catches in the Tolten estuary of Chile's Araucania Region between September and November, from 4 to $6 \mathrm{~cm}$ of total length and 0.3 to $0.4 \mathrm{~g}$. The fish were adapted to the diet over one month by gradually replacing bovine liver feed with formulated pelleted feed. b) Hatchery cultured fish in a $100 \mathrm{~L}$ fibre pond with well-aerated water with an exchange rate of 0.5 . The fish were feed by hand ad libitum three times a day six days a week, avoiding wasting food in the pond bottom.

In experiments (Exp.) 1 to 4, diets prepared with 3 to 5 levels of protein (treatments) and crumble size $\mathrm{N}^{\circ} 1$ (850 microns), the effect of different protein levels was evaluated with isocaloric (similar caloric value) pelleted diet with at least $27 \%$ up to $57 \%$. Each treatment had three ponds replicates. On this diet, the energy remained constant, and the protein and lipid per cents were balanced, increasing protein (fishmeal) and reducing lipid (fish oil). The diet ingredients such as "candaline binder" (durum wheat groats), meal and high quality fish oil used in salmon food were supplied by Skretting, Puerto Montt, Chile, and 
the vitamin supplements and minerals were supplied by Veterquimica, Santiago, Chile. Vita size 1 from Salmofood SA (Ext.V1) salmon commercial extruded diets were used as the reference diet. Per cent protein and lipid of the experiment diets:

Exps. 1 and 2.1: Pelleted Diets 1 to 3 with 27, 32, 37\% protein;

Exps. 2.2, 3 and 4: Pelleted Diets 1 to 5. Pelleted diet 4 has a higher protein level (56-57\%) and extruded Diet 5 was in:

a) Exp. 2.2: 53\% protein (NS: Salmon commercial Nutra Starter Trouw Chile, Skretting);

b) Exps. 3.1 and 3.2: 58\% protein (Ext. V1);

c) Exps. 4.1 and $4.2: 55 \%$ protein (Ext. V1).

The effect of different lipid levels was evaluated with extruded Salmon Nutra Starter (NS) isoproteic crumble 1 diet at $63 \%$ of experiment 5 , replicated in 4 ponds. The NS commercial diet is $21 \%$ lipid, which was compared with $8 \%$ by not adding fish oil to the diet.

\subsection{Pelletized diet elaboration methodology}

Fishmeal and "candealine binder" were sieved to 2000 , 850 and 600 microns. The estimated quantities of each ingredient were weighed and homogenized (fishmeal, vitamin and minerals premix, vitamin $C$ ) in a metallic container with a KitchenAid K5SS, USA, mixer for $30 \mathrm{~min}$. Then, the liquid ingredients were added; that is, fish oil and a mix of "candealine binder" with distilled water $(900 \mathrm{~mL}$ water $\mathrm{kg}^{-1}$ ). This mixture was boiled and stirred over low heat for $15 \mathrm{~min}$. and then passed through a $1 \mathrm{HP}$ Super Chacon (Chile) laboratory mixer, with a two or five $\mathrm{mm}$ gauge opening. The mixture was cold pressed for one hour until a homogeneous paste was obtained, pelletized and placed on trays covered with aluminium foil. The pellets were heated in a Memmert oven (Germany) at $60^{\circ} \mathrm{C}$ for 48 hours before being fragmented by a Moulinex grinder (France) and sifted to obtain the desired size of pellet granules (crumble 0: 600 microns, Vita 1 or crumble 1: 850 microns). The compositions of the experimental diets are shown in Table 2.

\subsection{Proximate analysis of pelletized diets}

The percentages of dry matter were determined by a gravimetric method after drying the pellets in a $105^{\circ} \mathrm{C}$ oven to constant weight. The total ash percentage was estimated by incinerating the samples in a Ney Vulcan A550, muffle (USA) at $600^{\circ} \mathrm{C}$ for 6 hours. The percentages of crude protein were determined $(\mathrm{N} \times 6.25)$ using the Kjeldahl method (AOAC, 1995) and the total lipid percentage was determined using a petroleum ether extraction method and the Soxhlet technique (Folch et al., 1957). Crude fibre was estimated by a double acid/alkaline attack (Windham, 1995). Carbohydrates and gross energy were estimated using Equations 1 and 2 (Maynard and Loosli, 1979):

Table 1. Number of ponds, experiment duration, number of fish, status, source and start weight range of G. maculatus specimens used in the five feeding experiment.

\begin{tabular}{cccccc}
\hline Exp. $\mathbf{N}^{\circ}$ & $\mathbf{N}^{\circ}$ pond & $\begin{array}{c}\text { Duration } \\
\text { (month) }\end{array}$ & $\mathbf{N}^{\circ}$ fish/ pond & $\begin{array}{c}\text { Status and } \\
\text { Source }\end{array}$ & $\begin{array}{c}\text { Start weight } \\
\text { range }(\mathbf{g})\end{array}$ \\
\hline 1.0 & 18 & 5 & 100 & Wild crystalline & 0.4 \\
2.1 & 18 & 5 & 50 & Wild adult & 1.4 \\
2.2 & 15 & 3 & 100 & Wild adult & 3.9 \\
3.1 & 15 & 3 & 150 & Wild adult & $1.1-1.8$ \\
3.2 & 15 & 3 & 200 & Wild adult & $1.4-2.0$ \\
4.1 & 15 & 3 & 100 & Wild crystalline & 0.5 \\
4.2 & 15 & 3 & 100 & Wild adult & $1.3-1.6$ \\
5.0 & 8 & 3 & 225 & Farmed crystalline & 0.6 \\
\hline
\end{tabular}

Table 2. Percentages of ingredients for the isocaloric pelleted diets with different percentages of fishmeal used in G. maculatus adult feeding experiments.

\begin{tabular}{lcccc}
\hline \multirow{2}{*}{ Ingredients (\%) } & \multicolumn{3}{c}{ Diet } \\
\cline { 2 - 5 } \multicolumn{1}{c}{} & $\mathbf{1}$ & $\mathbf{2}$ & $\mathbf{3}$ & $\mathbf{4}$ \\
\hline Fishmeal & 20 & 35 & 51 & 67 \\
Fish oil & 22 & 22 & 15 & 9 \\
Candealine & 57 & 43 & 33 & 23 \\
Vitamin/minerals Premix & 0.5 & 0.5 & 0.5 & 0.5 \\
Vitamin C (ascorbic acid) & 0.5 & 0.5 & 0.5 & 0.5 \\
Total & 100 & 100 & 100 & 100 \\
\hline
\end{tabular}




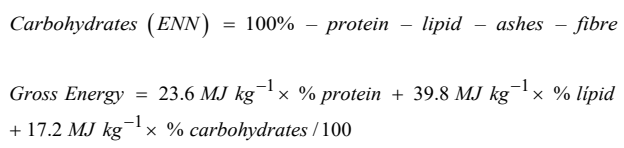

The results of the proximate analyses of the diets are shown in Table 3.

\subsection{Registration and measurement of parameters}

Minimum and maximum water pond temperature $\left({ }^{\circ} \mathrm{C}\right)$ and fish mortality were registered daily and used to calculate the daily mean temperature, $\%$ of monthly mortality and \% of accumulated mortality. Fish were anesthetized with $0.3 \mathrm{ml}$ benzocaine BZ2 $2 \mathrm{~L}^{-1}$ and monthly sampled by estimating the weight of 25 specimens per pond, which represents more than $5 \%$ of the fish, using an Ohaus (USA) balance with $0.1 \mathrm{~g}$ accuracy. Fish growth was estimated by using the following parameters: Monthly increase percentage in weight; daily increased percentage in weight; and Growth Factor 3. To evaluate monthly food efficiency, the Feed Conversion Ratio was used following the Dantagnan et al. (2012) methodology. Parameter averages, standard deviations and the coefficient of variation percentage from 3 replicates were also calculated. The crude protein energy ratio/total energy of the diet was estimated (Lee and Putnam, 1973) and the sexual maturity stages of $G$. maculatus specimens were determined using the macroscopic scale method of Valdebenito and Vega (2003).

\subsection{Statistical analysis}

From the results of \% monthly weight growth, only the first month from each treatment in experiments 1 to 4 were statistically analysed. The variability in the results from the second month is explained in the discussion. In experiment 5 , the first and second month were analysed. The results of $\%$ monthly weight growth (Table 4), previously an arcsine transformation, were compared by one way analysis of variance (ANOVA) followed by multiple comparisons between means using Tukey's test to detect differences (Zar, 1984). To estimate the equations in Table 5 of the logarithmic relationships in protein percentage and protein energy/total energy diets and monthly weight growth rate for different weights of $G$. maculatus the data used come from Table 4 . The protein optimal percentage in the diet was estimated by calculating the point where the straight $1(\%$ Growth $=7.6481+0.3153 \%$ Protein $)$ and $2(\%$ Growth $=$ $-1.8592+0.5542 \%$ Protein) are intercepted, and estimated by regression of the coordinates of the lower half and upper curve $(\%$ Growth $=-42.344+16.81 \%$ Protein $)$.

\section{Results}

\subsection{Effect of different levels of protein and energy on growth to adult weight in Galaxias maculatus}

The results show a tendency to increased weight in all sizes ( 0.4 to $3.9 \mathrm{~g}$ ) in G. maculatus with an increased protein level in the diet (Figure 1; Tables 4 and 5, Exps. 1 to 4). In experiment 3.1, the protein\% values rise from 26 to $56 \%$, showing significant differences $(P<0.05)$ in the monthly average growth in weight from 13 to $82 \%$; similar results are seen in Exp. 4.2 for the extruded diet (55\% of protein) with a $171 \%$ weight increase. In experiments $1,2.1$ and 3.1, diets under $32 \%$ protein are associated with a significantly lower growth $(P<0.05)$ than diets with a higher percentage of protein. The high variability in the results of diets with higher protein levels expressed in coefficient of variations from 24 to $61 \%$ reveal no significant differences with the diets with lower protein levels, for example Figure 2, Table 4, Exps. 1, 2.2 and 3.2. Water pond monthly mean temperatures fluctuated between 9.4 and $16.7^{\circ} \mathrm{C}$ and are shown for each experiment in Table 4.

The results also show that the monthly growth percentage depends on fish weight. On a higher weight but lower growing percentage, for pelletized diets between 37

Table 3. Average and standard deviation of proximal analysis of isocaloric pelleted diets with different percentages of fishmeal used in the experiments.

\begin{tabular}{|c|c|c|c|c|c|c|c|c|}
\hline \multirow{2}{*}{$\frac{\text { Diet }}{\text { \% Fishmeal in diet }}$} & \multicolumn{4}{|c|}{ Experimental } & \multicolumn{4}{|c|}{ Commercial } \\
\hline & 20 & 35 & 51 & 67 & NS & V1 & $\begin{array}{l}\text { With } \\
\text { FO }\end{array}$ & $\begin{array}{l}\text { Without } \\
\text { FO }\end{array}$ \\
\hline \multicolumn{9}{|l|}{ Mean \% Diet components } \\
\hline Dry matter & $93 \pm 5$ & $96 \pm 3$ & $92 \pm 2$ & $92 \pm 1$ & $93 \pm 1$ & 99 & 93 & 92 \\
\hline Crude protein $(\mathrm{N} \times 6.25)$ & $25 \pm 3$ & $31 \pm 1$ & $39 \pm 6$ & $48 \pm 10$ & $56 \pm 4$ & 55 & 63 & 62 \\
\hline $\begin{array}{l}\text { Lipid (Ether extr. } \\
\text { Soxhlet) }\end{array}$ & $16 \pm 4$ & $22 \pm 8$ & $16 \pm 4$ & $20 \pm 4$ & $17 \pm 4$ & 15 & 21 & 8 \\
\hline $\begin{array}{l}\text { Non-nitrogenated extr. } \\
\text { (ENN) }\end{array}$ & $54 \pm 5$ & $42 \pm 8$ & $36 \pm 11$ & $24 \pm 11$ & $20 \pm 8$ & 18 & 5 & 17 \\
\hline Total ash & $5 \pm 1$ & $4 \pm 3$ & $7 \pm 3$ & $8 \pm 1$ & $13 \pm 2$ & 11 & 11 & 13 \\
\hline Fibre & $1 \pm 1$ & $1 \pm 1$ & $1 \pm 1$ & $1 \pm 1$ & $1 \pm 0$ & 2 & 1 & 1 \\
\hline Gross Energy (MJ kg-1) & $21.35 \pm 0.9$ & $23.13 \pm 2.0$ & $21.78 \pm 0.9$ & $23.05 \pm 0.5$ & $23.15 \pm 2.2$ & 21.90 & 23.80 & 20.40 \\
\hline
\end{tabular}

NS= Nutra Starter Trow Chile Skretting; V1: Vita caliber 1 Salmofood; FO: Fish Oil. 


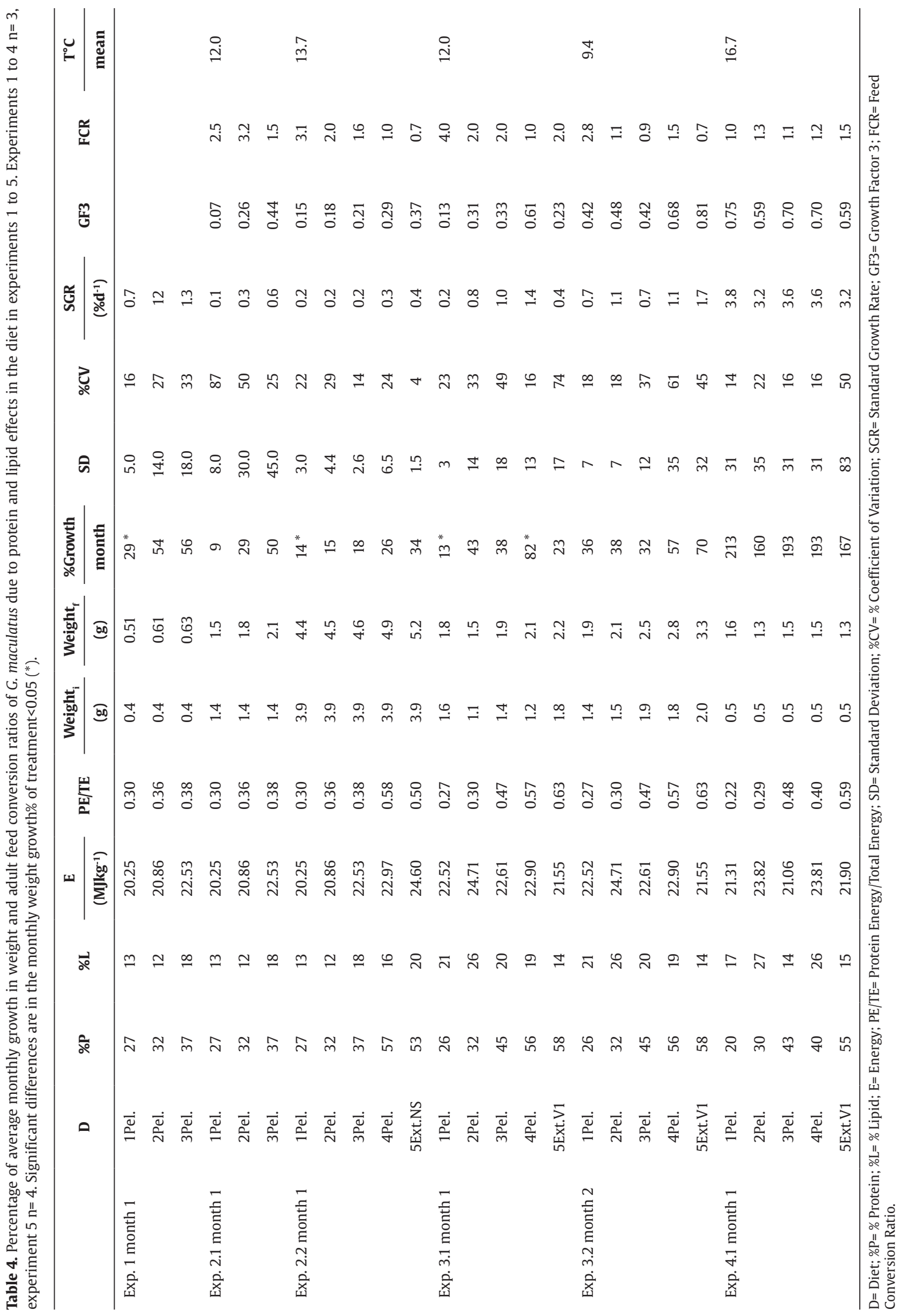




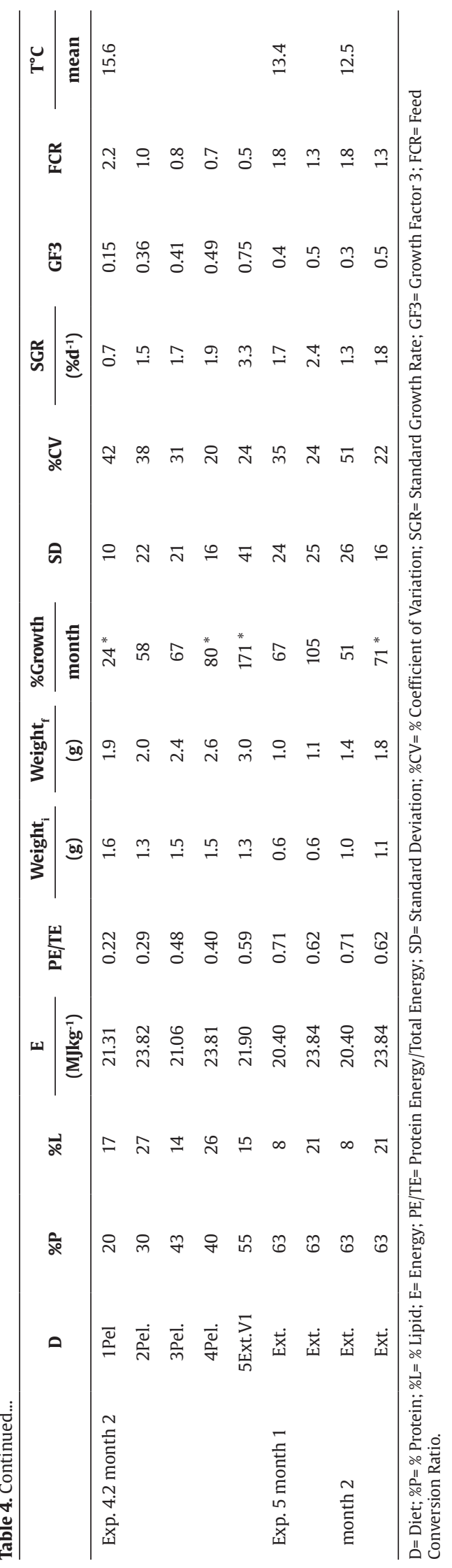


Table 5. Equations and correlation coefficients of the logarithmic relationships in protein percentage and protein energy/total energy diets (PE/TE) and monthly weight growth rate for different average weights of G. maculatus.

\begin{tabular}{|c|c|c|}
\hline Weight & Relation & Relation \\
\hline (g) & $\%$ protein - \%monthly growth & PE/TE - \%monthly growth n \\
\hline 0.4 & $Y=87.422 \ln (x)-25.930 r^{2}=0.84$ & $Y=120.040 \ln (x)+174.10 r^{2}=0.999$ \\
\hline 0.5 & & $Y=-10.440 \ln (x)+178.26 r^{2}=0.0315$ \\
\hline 1.3 & $Y=72.788 \ln (x)-220.870 r^{2}=0.76$ & $Y=65.372 \ln (x)+106.60 r^{2}=0.6715$ \\
\hline 1.4 & $Y=129.780 \ln (x)-419.370 r^{2}=0.99$ & $Y=157.250 \ln (x)+196.71 r^{2}=0.909$ \\
\hline 1.5 & $Y=65.001 \ln (x)-166.770 r^{2}=0.89$ & $\mathrm{Y}=59.777 \ln (\mathrm{x})+123.04 \mathrm{r}^{2}=0.7515$ \\
\hline 1.7 & $Y=20.134 \ln (x)-32.517 r^{2}=0.39$ & $Y=19.112 \ln (x)+36.11 r^{2}=0.9615$ \\
\hline 3.9 & $Y=16.813 \ln (x)-42.344 r^{2}=0.98$ & $Y=18.337 \ln (x)+58.31 r^{2}=0.3615$ \\
\hline
\end{tabular}

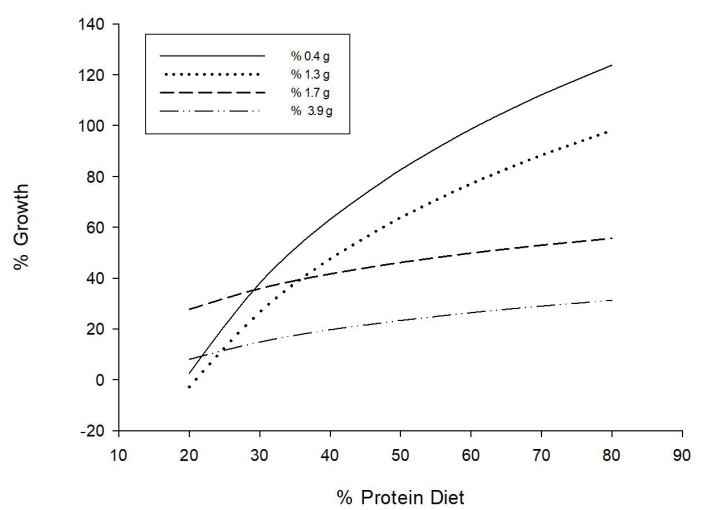

Figure 1. Logarithmic trend ratio of the percentage of protein in the diets and monthly growth rate for different weights of $G$. maculatus, with points estimated from Table 5 equations.

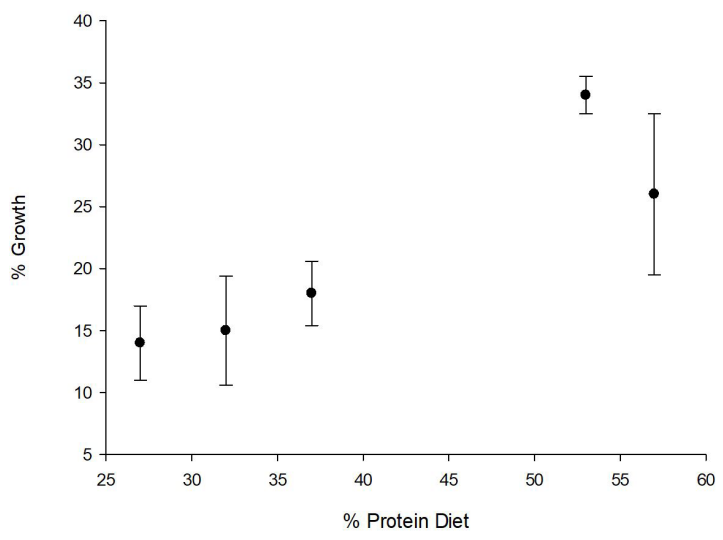

Figure 2. Growth percentage of G. maculatus pelletized fed diets containing different protein levels in Experiment 2.2. Extruded diet $53 \%$ protein.

and $57 \%$ of protein, there was maximum growth from 193 to $26 \%$ monthly in newly metamorphosed juveniles from 0.4 to 3.9 g adults. Higher growth for different weights is associated with lower feed conversion ratios, fluctuating between 0.7 and 1.5, in a protein energy/total energy (PE/TE) ratio of 0.38 to 0.58 and diet energy from 21.06 to $23.81 \mathrm{MJ} \mathrm{kg}^{-1}$ (Table 4 ).

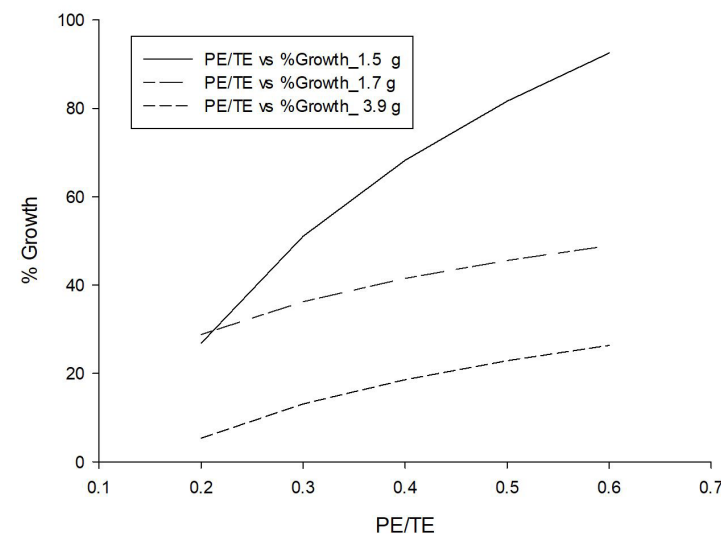

Figure 3. Logarithmic relationship trend between protein energy/ total energy (PE/TE) diet and percentage monthly growth rate of three weights of $\mathrm{G}$. maculatus $(1.5,1.7$ and $3.9 \mathrm{~g})$, with estimated points from Table 5 equations.

From an energetic approach, the results also show that there is a tendency to a linear trend between the energy of the diet $\left(\mathrm{MJ} \mathrm{kg}^{-1}\right)$ and the \% of weight increase (e.g. Exp. 2.1: $\left.\mathrm{Y}=16.831 \mathrm{X}-327.84 \mathrm{R}^{2}=0.9337\right)$. The logarithmic relationship (protein energy/total energy of the diet) as it increases from 0.2 to 0.6 increases the monthly weight growth percentage of G. maculatus (Figure 3, Tables 4 and 5, Exps. 1, 3.1, 3.2 and 4.1). Lower weight adult fishes with a low PE/TE ratio of 0.3 in their diet have a low monthly growth rate ( $0.4 \mathrm{~g}: 30 \%$ to $1.4 \mathrm{~g}: 7 \%$ ) and with a high ratio (0.6), a higher growth rate (116 to $73 \%$ ) (Table 5). Higher weight adult fishes and a low PE/TE diet ratio of 0.2 also show low monthly growth (1.7 g: $29 \%$ to $3.9 \mathrm{~g}: 5 \%$ ) and with a 0.6 ratio show the strongest growth (49 and $26 \%$, Figure 3).

The results show that a higher \% protein in the diet or growth in weight lower feed conversion ratio. The feed conversion ratio in the pelleted diets vary from 0.7 to 1.5 and in the extruded reaches up to 0.5 (Figures 4 and 5, Exps. 2.1, 2.2, 3.2 and 4.2).

When a commercial extruded salmon diet is compared with an experimental pelleted diet, in three out of four experiments, G. maculatus growth was greater on the extruded diet with a lower feed conversion ratio (Table 4). 


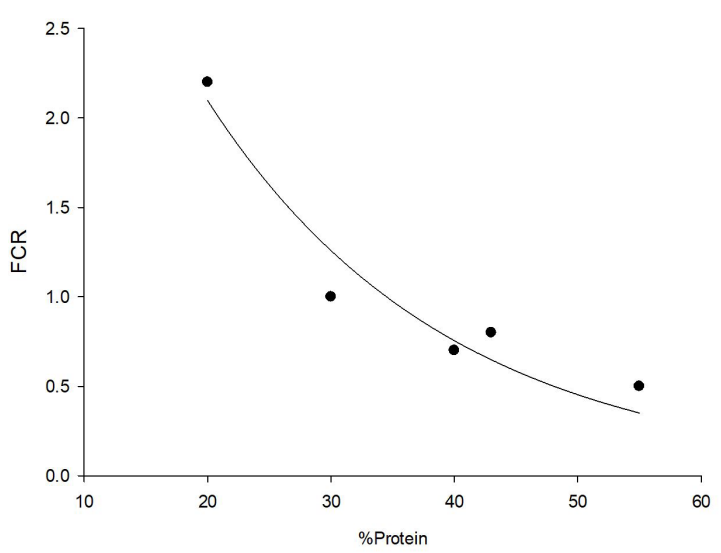

Figure 4. Potential negative trend of protein percentage in diets $\mathrm{v} / \mathrm{s}$ feed conversion ratio (FCR) in Experiment 4.2. $\mathrm{Y}=134.8 \mathrm{X}^{-1.4}$ $\mathrm{R}^{2}=0.955$.

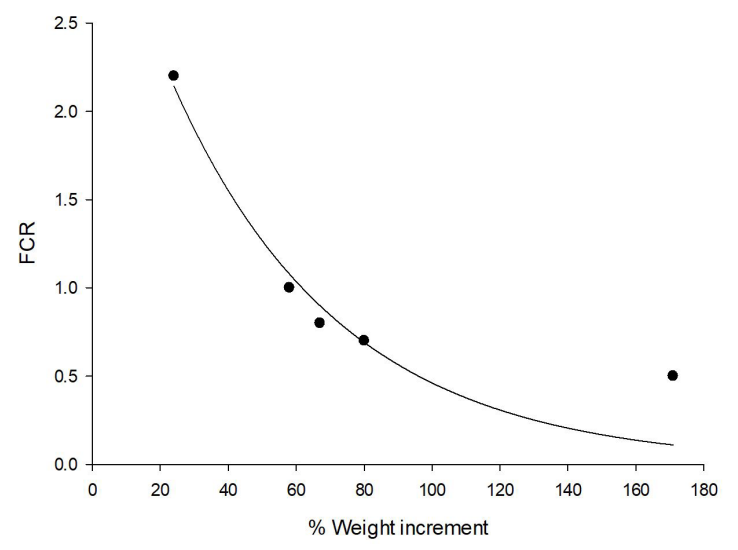

Figure 5. Potential negative trend in the monthly percentage increase in weight $\mathrm{v} / \mathrm{s}$ feed conversion ratio (FCR) diets in Experiment 4.2. $\mathrm{Y}=22.9 \mathrm{X}^{-0.7702} \mathrm{R}^{2}=0.96$.

Growth differences between both types of diet vary between 8 and 91\% (Exps. 2.2 and 4.2), even with the significant differences in experiment $4.2(P<0.05)$. This trend of higher growth and smaller feed conversion ratio in the extruded diet happens when the extruded diet in experiment 2.2 (Figure 2) is higher than the pelleted one $\left(24.60 \mathrm{v} / \mathrm{s} 22.97 \mathrm{MJ} \mathrm{kg}^{-1}\right)$ with a lower protein level (53 v/s 57\%), such as in experiment 4.2, where extruded diet had lower energy levels ( $\left.21.90 \mathrm{v} / \mathrm{s} 23.81 \mathrm{MJ} \mathrm{kg}^{-1}\right)$ but higher protein levels ( $55 \mathrm{v} / \mathrm{s} 40 \%$ ). Only in experiment 4.1 did the pelleted diet generate a higher average monthly growth (213\%) then the extruded one (167\%); however, no significant differences were found $(P>0.05)$ and the feed conversion ratio was lower $(1.1 \mathrm{v} / \mathrm{s} 1.5)$. Pelleted and extruded diets have similar energy values (21.06 and $21.90 \mathrm{MJ} \mathrm{kg}^{-1}$ ), unless the pelletized diet is less compared to the extruded one, where the PE/TE value $(0.48<0.59)$ and protein level is $43 \%<55 \%$. Extruded feed conversion ratios are less for the pelleted diets $(0.7 \mathrm{v} / \mathrm{s} 1.0 ; 0.7 \mathrm{v} / \mathrm{s} 1.5$ and $0.5 \mathrm{v} / \mathrm{s} 0.7$ ) and PE/TE values between the same pelleted and extruded diets are either higher or lower $(0.50<0.58$;
$0.63>0.57$ and $0.59>0.40$ ). These results suggest that: a) A pelleted diet with a varying $P E / T E$ ratio does not increase growth or a lower feed conversion ratio than an extruded diet with similar protein and lipid levels. b) There is an effect of the food preparation process where food extrusion affects growth and feed conversion ratios.

In the experiments, fish growth is affected by diseases causing mortality and sexual maturity. A monthly mean mortality of 5 to $45 \%$ is higher than usual in fish farming and some replicates are affected by diseases increasing mortality and decreasing fish number per pond; e.g., $48 \%$ in the extruded diet of Exp. 4.2, due to flavobacteriosis. The fast initial sexual maturity of the specimens prevented continuing the experiments for more than 30 to 60 days (Exps. 2.1, 3.1) because the fish start to mature, returning from the sea as crystalline juvenile and metamorphosing into adults when returning to fresh water. The monthly mean sexual maturity of the specimens ranged between 0 and 85\% (Exps. 2.1, 2.2, 3.1 and 5). No direct relationship between mortality and sexual maturation was observed in the experiments and there were no significant differences $(P>0.05)$ between fish maturity percentages with different protein levels in the diet (Exps. 2.2 and 3.1). However, there is a trend $\left(\mathrm{Y}=0.693 \mathrm{X}+39.723, \mathrm{R}^{2}=0.8341\right)$ where increasing the level of dietary protein increases sexual maturity; e.g., from 30 to $60 \%$ protein increased sexual maturity from 60 to $80 \%$ in Exp. 3.1 .

\subsection{Effect of two level lipid content at a similar protein level in the extruded diet on the increase in weight of G. maculatus}

In $0.6 \mathrm{~g}$ specimens of $G$. maculatus fed a $63 \%$ protein and an extruded commercial diet with two different lipid levels, when increased from 8 to $21 \%$, (20.40 to $23.84 \mathrm{MJ} \mathrm{kg}^{-1}$ ) and ratio PE/TE 0.71 to 0.62 , the first month weight increase ranged from 67 to $105 \%$. In the second month, in $1.1 \mathrm{~g}$ fish, from 51 to $71 \%$, there were significant differences in growth $(P<0.05)$ between the lipid levels (Table 4 Exp. 5). The fish, as they grow from one month to the next, slow down their growth. Growing fish had a slower weight growth rate, as shown in the second month growth percentages.

The diet composed of $63 \%$ protein and $21 \%$ lipid has a higher energy content (23.84 $\left.\mathrm{MJ} \mathrm{kg}^{-1}\right)$, a higher growth and the best feed conversion ratio (1.3) compared to the lower lipid diet (8\%). This result agrees with the higher increases in weight (105 and 71\%) and lower variability (\%CV $=24$ and 22) in month 1 and 2 (Table 4 Exp. 5). In these two diets, a $21 \%$ monthly mortality was observed, with $100 \%$ of fishes mature and with no significant differences between the diets $(P>0.05)$.

\subsection{Minimum protein level in a diet for maximum adult growth in G. maculatus}

The results show that maximal G. maculatus adult growth is obtained with a diet containing a minimum of $37 \%$ crude protein, with $40 \%$ the optimal value. With protein above this level, the growth percentage increases, reaching a maximum between 50 and 60\% (Figure 6). 


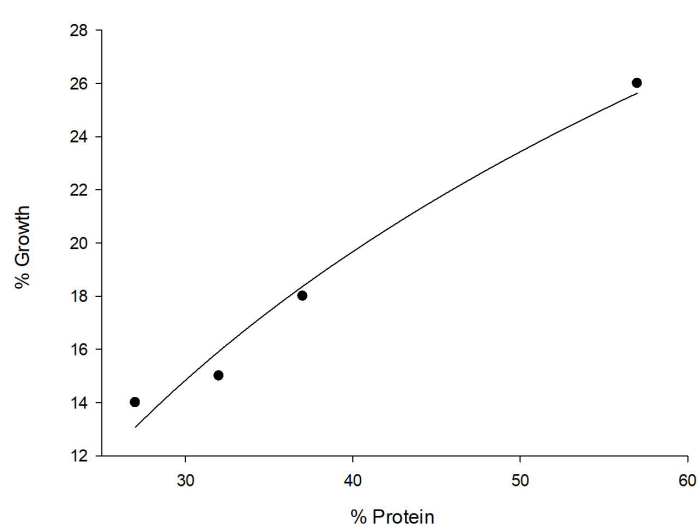

Figure 6. Logarithmic ratio of pelleted protein diet percentage versus monthly growth percentage in G. maculatus in Experiment 2.2. $\mathrm{Y}=16.81 \ln (\mathrm{X})-42.34 \mathrm{R}^{2}=0.977$.

\subsection{Ratio of protein energy vs. total diet energy}

The highest monthly percentage growth $(82 \%)$ is observed for the $0.57 \mathrm{PE} / \mathrm{TE}$ ratio, $22.90 \mathrm{MJ} \mathrm{kg}^{-1}, 56 \%$ protein and 19\% lipid pelleted diet (Table 4 Exp. 3.1). The highest G. maculatus adult growth was obtained on the 0.38 to 0.58 PE/TE ratio, 22.53 to $23.81 \mathrm{MJ} \mathrm{kg}^{-1}$ energy level, 37 to $57 \%$ protein level and 16 to $26 \%$ lipid level pelletized diet. The extruded diet was associated with higher growth rates than the pelleted diets and the best results (171\%) were obtained for the $0.59 \mathrm{PE} / \mathrm{TE}$ ratio, $21.90 \mathrm{MJ} \mathrm{kg}^{-1}$ energy level, $55 \%$ protein level and 15\% lipid level (Exp. 4.2). In this diet, the PE/TE ratio was in the 0.50 to 0.63 range, with energy values from 21.55 to $24.60 \mathrm{MJ} \mathrm{kg}^{-1}$, protein levels from 53 to $63 \%$ and lipid levels from 14 to $21 \%$. The G. maculatus protein retention efficiency (PPV) decreases as the protein increases in the diet. The ratio is expressed in the equation: $\mathrm{PPV}=87.293-1.160\left(\mathrm{PE} / \mathrm{TE}^{*} 100\right)$ and predicts a $41 \% \mathrm{PPV}$ at $10^{\circ} \mathrm{C}$ when the PE/TE ratio is optimal $(0.40)$.

\section{Discussion}

\subsection{Protein level affects growth}

Protein requirements for optimal growth (Garling Junior and Wilson, 1976; NRC, 2011) show a general trend such that at a higher protein level, a higher growth is obtained, reaching an asymptote when the optimal level is exceeded (Shi et al., 1988). This pattern is consistent with the 2.2, 3.1 and 4.2 experimental results (Table 4, Figures 1 and 7), where the optimum is $37 \%$ for $0.4 \mathrm{~g}$ samples. Protein levels below $30 \%$ generate significantly lower growth $(P<0.05)$. Between 50 and $60 \%$ protein, higher growth and lower feed conversion ratios are observed (0.5 to 0.7$)$. This value is similar to other carnivorous fish species (Cho and Kaushik, 1990; Tibaldi et al., 1996; Vergara et al., 1996b; Lupatsch et al., 2001; Refstie et al., 2001; Lee and Kim, 2001; Nordgarden et al., 2002; Schuchardt et al., 2008; Jiang et al., 2016).

The protein energy/total energy ratio in a diet is an indicator used to estimate the protein level in fishes (Lee and Putnam, 1973; Santinha et al., 1999; Skalli et al., 2004, Rahimnejad et al., 2015; Jiang et al., 2016). In G. maculatus adults, it corresponds to 0.57 and 0.59 , reaching the highest growth in extruded and pelletized diets, indicating that a high energy input from protein is required to express their maximum growth. These values are higher than for other species; therefore, growth outcomes with protein levels over $30 \%$ are similar to rainbow trout (Oncorhynchus mykiss) and arctic char (Salvelinus alpinus), requiring diets with an energy ratio of at least 0.35 to retain good growth rates (Jobling and Wandsvik, 1983). In G. maculatus, the protein retention efficiency ratio (PPV) decreases with increased protein content in the diet, at 41\% PPV when the $\mathrm{PE} / \mathrm{TE}$ ratio is optimum $(0.40)$ at $10^{\circ} \mathrm{C}$. Similar values were obtained for rainbow trout at $12^{\circ} \mathrm{C}$ within the optimum value range between 30 to $40 \%$. Thus, when the diet is high in protein $(\mathrm{PE} / \mathrm{TE}=0.70)$ it is poorly utilized for growth (Wandsvik and Jobling, 1982, Wang et al., 2016).

\subsection{Lipid and energy affect growth}

Increased lipid and energy in the diet allows a protein saving effect or sparing effect (Vergara et al., 1996a; Weatherup et al., 1997; Company et al., 1999; Chatzifotis et al., 2010, Ding et al., 2010., Xu et al., 2015), as well increasing the growth rate and reducing the feed conversion ratio in G. maculatus (Exp. 5). When an isoproteic extruded diet is compared (63\%) with two lipid and energy levels, at the highest lipid (21\%) and energy (23.84 MJ $\left.\mathrm{kg}^{-1}\right)$ level, a significant difference $(P<0.05)$ is obtained in the second month with the $8 \%$ lipid $20.40 \mathrm{MJ} \mathrm{kg}^{-1}$ energy diet, with a higher growth rate (71\%) and a lower feed conversion ratio (1.3). In this experiment, a monthly high mortality is repeated (21\%) and $100 \%$ of $0.6 \mathrm{~g}$ fish initiate sexual maturity. It is remarkable that in all experiments, G. maculatus specimens recently metamorphosed to adults start to mature, therefore decreasing the weight growth rate.

\subsection{Food processing technique effect}

Usually, high lipid extruded diets are associated with higher growth and lower feed conversion ratios than pelleted diets in G. maculatus, with results similar to those found by Aksnes et al. (1997), Peres and Oliva Teles (1999), Vergara et al. (1999), Deng et al. (2011), Shapawi et al. (2014), Jiang et al. (2015) and García-Meilán et al. (2016). This is possibly a food extrusion process effect, which for different species improves the digestibility of protein (Deguara, 1997; Pérez et al., 1997; Sørensen et al., 2002), lipids (Peres and Oliva Teles, 1999; Boujard et al., 2004) and carbohydrate (Jeong et al., 1991). In addition, the extrusion process enables one to add more lipid to the diet and hence more energy. This process seems to lead to less protein (53\%) extruded food digestion, but more lipid (20\%) and energy (24.60 $\mathrm{MJ} \mathrm{kg}^{-1}$ ), generating a higher growth with a lower feed conversion ratio than pelleted food, and with more similar characteristics (Exp. 2.2: $57 \%$ protein, 16\% lipid and $22.97 \mathrm{MJ} \mathrm{kg}^{-1}$ ). Again Exp. 4.2 revealed that an extruded diet is associated with a better growth (171\%) and feed conversion ratio (0.5), although pelleted diets exceed lipid and energy levels. 


\subsection{Methodological considerations of experiments}

Food and frequency: Food was given ad libitum to avoid limiting growth and to guarantee food access to all fish. We estimated that at three daily feedings, one more than used by Jobling and Wandsvik (1983), satiety is reached. This diet approaches the maximum rate that promotes growth, avoiding the loss of food in the bottom of the pond, altering the estimation of food utilization efficiency.

Size: The small size of $G$. maculatus juveniles at metamorphosis to adults of $0.4 \mathrm{~g}$ has an effect on the experimental methodology, given that the adult weight used in experiments varied from 0.4 to $3.9 \mathrm{~g}$, constituting a small biomass that requires an even smaller amount of food. For this reason, a pelletized technique was used to provide the small amounts of food required at different protein levels in the test diets.

Diet formulation and elaboration: An isocaloric formulation was designed for pelleted diets to compare the effect of protein level on G. maculatus growth. However, the pelleting technique does not allow for the regulation of a high per cent of lipid, leading to variability in amount and consequently in energy.

Wild populations and weight growth variability: Because the farming technology is new and still developing on an experimental basis in G. maculatus, we do not have domestic populations. Therefore, these experiment were undertaken in wild populations captured in their spring return to the estuary. The results in the experiments were affected mainly by mortality and sexual maturation. Monthly mortalities fluctuated in a range between 0 and 48\%, possibly to stress, but certainly associated with the various endoparasites that they carry. Additionally, in captivity, they suffer epidemic diseases, such as Ich, flavobacteriosis and Salmon Rickettsial Syndrome (Vega et al., 2013). Disease probably affected growth, but certainly deaths decreased the numbers of specimen in the ponds, affecting weight averages, standard deviations and feed conversion ratios.

G. maculatus is a rapidly maturing fish once it reaches adulthood post-metamorphosis at $0.4 \mathrm{~g}$, something that was not known previously. Therefore, experiments were begun immediately once the fish were adapted to eat pellets. However, the adults began to mature quickly, from 50 to $100 \%$ in 30 to 60 days, which affected weight growth rates. Thus, the experiments were short term of 3 to 5 months (Table 1) and only the first month's data growth, one or two was considered. Therefore, the experiments must be repeated to obtain and verify clear results and reveal significant differences between the diets. Weight growth results after the first or second month were not considered. Due to mortality and sexual maturation, they exhibit grater variability that prevents statistically differentiating the effect on protein levels of the diets.

\section{Conclusion}

The results of this work are the first to demonstrate that G. maculatus, as a carnivorous fish, requires high protein, lipid and energy levels in extruded diets to grow faster and generate lower feed conversion ratios.

\section{Acknowledgements}

The authors acknowledge the financial support of the following projects: DIUCT 2004-03-1 from the Universidad Católica de Temuco (Catholic University of Temuco), FONDECYT 1930134, D96-I1071, and Mecesup UCT 0804. Additionally, our thanks to the referees who helped us improve the manuscript.

\section{References}

AKSNES, A., 1995. Growth, feed efficiency and slaughter quality of salmon, Salmo salar L., given feeds with different ratios of carbohydrate and protein. Aquaculture Nutrition, vol. 1, no. 4, pp. 241-248. http://dx.doi.org/10.1111/j.1365-2095.1995.tb00050.x.

AKSNES, A., IZQUIERDO, M.S., ROBAINA, L., VERGARA, J.M. and MONTERO, D., 1997. Influence of fish meal quality and feed pellet on growth, feed efficiency and muscle composition in gilthead seabream (Sparus aurata). Aquaculture (Amsterdam, Netherlands), vol. 153, no. 3-4, pp. 251-261. http://dx.doi. org/10.1016/S0044-8486(97)00046-X.

ASSOCIATION OF ANALYTICAL CHEMISTS - AOAC, 1995. Official methods of analysis. 16th ed. Washington: AOAC.

BARILE, J., BORQUEZ, A., DANTAGNAN, P., MARDONES, A., QUEVEDO, J., SALGADO, I., VALDEBENITO, I. and VEGA, R., 2003 [viewed 5 November 2019]. Antecedentes para el cultivo del puye Galaxias maculatus (Pisces: Galaxiidae) [online]. Editorial Graficasur Ltda., pp. 144. Available from: http://repositoriodigital.uct.cl/ handle/10925/523.

BOUJARD, T., GÉLINEA, A., COVÉS, D., CORRAZE, G., DUTTO, G., GASSET, E. and KAUSHIK, S., 2004. Regulation in feed intake, growth, nutrient and energy utilization in European sea bass (Dicentrarchus labrax) fed high fat diet. Aquaculture (Amsterdam, Netherlands), vol. 231, no. 1-4, pp. 529-545. http://dx.doi. $\operatorname{org} / 10.1016 / j$.aquaculture.2003.11.010.

BROMAGE, N.R., 1995. Broodstock management and seed qualitygeneral considerations. In: N.R. BROMAGE and R.J. ROBERTS, eds. Broodstock management and egg and larval quality. Cambridge: Cambridge University Press, pp. 24.

CHATZIFOTIS, S., PANAGIOTIDOU, M., PAPAIOANNOU, N., PAVLIDIS, M., NENGAS, I. and MYLONAS, C.C., 2010. Effect of dietary lipid levels on growth, feed utilization, body composition and serum metabolites of meagre (Argyrosomus regius) juveniles. Aquaculture (Amsterdam, Netherlands), vol. 307, no. 1, pp. 65-70. http://dx.doi.org/10.1016/j.aquaculture.2010.07.002.

CHO, C.Y. and KAUSHIK, S.J., 1990. Nutritional energetics in fish: protein and energy utilization in rainbow trout. In: G.H. BOURNE, ed. Aspects of food production, consumption and energy values. Basel, Switzerland: Karger, pp. 132-172. World Review of Nutrition and Dietetics, vol. 61.

CHO, C.Y., 1992. Feeding systems for rainbow trout and other salmonids with reference to current estimates and protein requirements. Aquaculture (Amsterdam, Netherlands), vol. 100, no. $1-3$, pp. 107-123. http://dx.doi.org/10.1016/00448486(92)90353-M.

COMPANY, R., CALDUCH-GINER, J.A., PÉREZ-SÁNCHEZ, J. and KAUSHIK, S.J., 1999. Protein sparing effect of dietary lipids in common dentex (Dentex dentex): a comparative study with sea bream (Sparus aurata) and sea bass (Dicentrarchus labrax). Aquatic Living Resources, vol. 12, pp. 23-30. http://dx.doi. org/10.1016/S0990-7440(99)80011-4. 
COWEY, C.B. and SARGENT, J.R., 1979. Nutrition. In: W.S. HOAR, D.J. RANDALL and J.R. BRETT, editors. Fish ohysiology. New York: Academic Press, pp. 1-69 pp. vol. 111: Bioenergetics and Growth.

DANTAGNAN, P., DOMINGUEZ, A., BORQUEZ, A., ALCAÍNO, J., PAVEZ, C. and HERNANDEZ, A., 2012. Influencia del alfa tocoferol en la incorporación y peroxidación del ácido araquidónico en alevines parr de salmón del atlántico (Salmo salar L.). Latin American Journal of Aquatic Research, vol. 40, no. 3, pp. 562-577. http:// dx.doi.org/10.3856/vol40-issue3-fulltext-6.

DE SILVA, S. and ANDERSON, T., 1995. Fish nutrition in aquaculture. Aquaculture (Amsterdam, Netherlands), vol. 6, pp. 151-158.

DEGUARA, S., 1997. Evaluation of different pressed and extruded fish meal based diets on the growth of gilthead sea bream, Sparus aurata L. In: A.G.J. TACON and B. BASURCO, eds. Feeding tomorrow's fish. Spain: Zaragoza CIHEAM, pp. 123-139. Cahiers Options Méditerranéennes; no. 22.

DENG, D.F., JU, Z.Y., DOMINY, W., MURASHIGE, R. and WILSON, R.P., 2011. Optimal dietary protein levels for juvenile pacific threadfin (Polydactylus sexfilis) fed diets with two levels of lipid. Aquaculture (Amsterdam, Netherlands), vol. 316, no. 1, pp. 25-30. http://dx.doi.org/10.1016/j.aquaculture.2011.03.023.

DING, L., ZHANG, L., WANG, J., MA, J., MENG, X., DUAN, P. and SUN, Y., 2010. Effect of dietary lipid level on the growth performance, feed utilization, body composition and blood chemistry of juvenile starry flounder (Platichthys stellatus). Aquatic Research, vol. 41, no. 10, pp. 1470-1478.

FOLCH, J., LEES, M. and STANLEY, G.H.S., 1957. A simple method for the isolation and purification of total lipids from animal tissues. The Journal of Biological Chemistry, vol. 226, no. 1, pp. 497-509. http://dx.doi.org/10.1016/S0021-9258(18)64849-5. PMid:13428781.

GARCÍA-MEILÁN, I., ORDÓÑEZ-GRANDE, B., MACHAHUA, C., BUENESTADO, S., FONTANILLAS, R. and GALLARDO, M.A., 2016. Effects of dietary protein-to-lipid ratio on digestive and absorptive processes in sea bass fingerlings. Aquaculture (Amsterdam, Netherlands), vol. 463, pp. 163-173. http://dx.doi. $\operatorname{org} / 10.1016 / j$.aquaculture.2016.05.039.

GARLING JUNIOR, D.L. and WILSON, R.P., 1976. Optimum dietary protein to energy ratio for channel catfish fingerlings, Ictalurus punctatus. The Journal of Nutrition, vol. 106, no. 9, pp. 13681375. http://dx.doi.org/10.1093/jn/106.9.1368. PMid:956918.

JEONG, K.-S., TAKEUCHI, T. and WATANABE, T., 1991. Improvement of nutritional quality of carbohydrate ingredients by extrusion process in diets of red sea bream. Nippon Suisan Gakkaishi, vol. 57, no. 8, pp. 1543-1549. http://dx.doi.org/10.2331/suisan.57.1543.

JIANG, S., WU, X., LUO, Y., WU, M., LU, S., JIN, Z. and YAO W., 2016. Optimal dietary protein level and protein to energy ratio for hybrid grouper (Epinephelus fuscoguttatus $\odot \times$ Epinephelus lanceolatus $\lesssim$ ) juveniles. Aquaculture, vol. 465, pp. 28-36. http:// dx.doi.org/10.1016/j.aquaculture.2016.08.030.

JIANG, S.T., WU, X.Y., LI, W.F., WU, M.J., LUO, Y., LU, S.D. and LIN, H.R., 2015. Effects of dietary protein and lipid levels on growth, feed utilization, body and plasma biochemical compositions of hybrid grouper (Epinephelus lanceolatus $\lesssim \times$ Epinephelus fuscoguttatus + ) juveniles. Aquaculture (Amsterdam, Netherlands), vol. 446, pp. 148-155. http://dx.doi.org/10.1016/j.aquaculture.2015.04.034.

JOBLING, M. and WANDSVIK, A., 1983. Quantitative protein requirements of Arctic charr, Salvelinus alpinus (L). Journal of Fish Biology, vol. 22, no. 6, pp. 705-712. http://dx.doi. org/10.1111/j.1095-8649.1983.tb04230.x.

LEE, D.J. and PUTNAM, G.B., 1973. The response of rainbow trout to varying protein/energy ratios in a test diet. The Journal of
Nutrition, vol. 103, no. 6, pp. 916-922. http://dx.doi.org/10.1093/ jn/103.6.916. PMid:4705278.

LEE, S.M. and KIM, K.D., 2001. Effects of dietary protein and energy levels on the growth, protein utilization and body composition of juvenile masu salmon (Oncorhynchus masou Brevoort). Aquaculture Research, vol. 32, pp. 39-45. http:// dx.doi.org/10.1046/j.1355-557x.2001.00004.x.

LUPATSCH, I., KISSIL, G.W., SKLAN, D. and FEFFER, E., 2001. Effects of varying dietary protein and energy supply on growth, body composition and protein utilization in gilthead sea bream (Sparus aurata L.). Aquaculture (Amsterdam, Netherlands), vol. 7, pp. 71-80.

MARDONES, A., VEGA, R. and ENCINA, F., 2008. Cultivation of Whitebait (Galaxias maculatus) in Chile. Aquaculture Research, vol. 39, no. 7, pp. 731-737. http://dx.doi.org/10.1111/j.13652109.2008.01925.x.

MAYNARD, L.A. and LOOSLI, J.K., 1979. Animal nutrition. 7th ed. New York: McGraw-Hill, pp. 602.

MITCHELL, C., 1989. Laboratory culture of Galaxias maculatus and potential applications. New Zealand Journal of Marine and Freshwater Research, vol. 23, no. 3, pp. 325-336. http://dx.doi. org/10.1080/00288330.1989.9516369.

NATIONAL RESEARCH COUNCIL - NRC, 2011. Nutrient requirements of fish and shrimp. Washington: National Academies Press, pp. 71-73.

NORDGARDEN, U., HEMRE, G.I. and HANSEN, T., 2002. Growth and body composition of Atlantic salmon (Salmo salar L.) parr and smolt fed diets varying in protein and lipid contents. Aquaculture (Amsterdam, Netherlands), vol. 207, no. 1-2, pp. 65-78. http:// dx.doi.org/10.1016/S0044-8486(01)00750-5.

PERES, H. and OLIVA TELES, A., 1999. Effect of dietary lipid level on growth performance and feed utilization by European sea bass (Dicentrarchus labrax). Aquaculture (Amsterdam, Netherlands), vol. 179, no. 1-4, pp. 325-334. http://dx.doi.org/10.1016/S00448486(99)00168-4.

PÉREZ, L., GONZÁLEZ, H., JOVER, M. and FERNÁNDEZ-CARMONA, J., 1997. Growth of European sea bass fingerlings (Dicentrarchus labrax) fed extruded diets containing varying levels of protein, lipid and carbohydrate. Aquaculture (Amsterdam, Netherlands), vol. 156, no. 3-4, pp. 183-193. http://dx.doi.org/10.1016/S00448486(97)00089-6.

RAHIMNEJAD, S., BANG, I.C., PARK, J.Y., SADE, A., CHOI, J. and LEE, S.M., 2015. Effects of dietary proteín and lipid levels on growth performance, feed utilization and body composition of juvenile hybrid grouper, Epinephelus fuscoguttatus $\times$ E. lanceolatus. Aquaculture (Amsterdam, Netherlands), vol. 446, pp. 283-289. http://dx.doi.org/10.1016/j.aquaculture.2015.05.019.

REFSTIE, S., STOREBAKKEN, T., BAEVERFJORD, G. and ROEM, A.J., 2001. Longterm protein and lipid growth of Atlantic salmon (Salmo salar) fed diets with partial replacement of fish meal by soy protein products at medium or high lipid level. Aquaculture (Amsterdam, Netherlands), vol. 193, no. 1-2, pp. 91-106. http:// dx.doi.org/10.1016/S0044-8486(00)00473-7.

SANTINHA, P.J.M., MEDALE, F., CORRAZE, G. and GOMES, E.F.S., 1999. Effects of the dietary protein/lipid ratio on growth and nutrients utilization in gilthead seabream (Sparus aurata L). Aquaculture Nutrition, vol. 5, no. 3, pp. 147-156. http://dx.doi. org/10.1046/j.1365-2095.1999.00107.x.

SCHUCHARDT, D., VERGARA, J.M., FERNÁNDEZ-PALACIOS, H., KALINOWSKI, C.T., HERNÁNDEZ-CRUZ, C.M., IZQUIERDO, M.S. and ROBAINA, L., 2008. Effects of different dietary protein and lipid levels on growth, feed utilization and body composition 
of red porgy (Pagrus pagrus) fingerlings. Aquaculture Nutrition, vol. 14, pp. 1-9.

SHAPAWI, R., EBI, I., YONG, A.S.K. and NG, W.K., 2014. Optimizing the growth performance of brown-marbled grouper, Epinephelus fuscoguttatus (Forskal), by varying the proportion of dietary protein and lipid levels. Animal Feed Science and Technology, vol. 191, pp. 98-105. http://dx.doi.org/10.1016/j. anifeedsci.2014.01.020.

SHI, W., SHAN, J. and LIU, M., 1988. Study on the optimum demand of protein by blunt-nose bream (Megalobrama amblycephala). In: Congress Proceedings: Aquaculture International Congress $\mathcal{E}$ Expositio, 1988, Vancouver. Canada: British Columbia Pavilion Corporation, pp. 92-95.

SKALLI, A., HIDALGO, M.C., ABELLÁN, E., ARIZCUN, M. and CARDENETE, G., 2004. Effects of the dietary protein/lipid ratio on growth and nutrient utilization in common dentex (Dentex dentex L.) at different growth stages. Aquaculture (Amsterdam, Netherlands), vol. 235, no. 1-4, pp. 1-11. http:// dx.doi.org/10.1016/j.aquaculture.2004.01.014.

SøRENSEN, M., LJØKJEL, K., STOREBAKKEN, T., SHEARER, K.D. and SKREDE, A., 2002. Apparent digestibility of protein, amino acids and energy in rainbow trout (Oncorhynchus mykiss) fed a fish meal based diet extruded at different temperatures. Aquaculture (Amsterdam, Netherlands), vol. 211, no. 1-4, pp. 215-225. http://dx.doi.org/10.1016/S0044-8486(01)00887-0.

TACON, A.G.J. and COWEY, C., 1985. Protein and amino acid requirements. In: P. TYTLER and P. CALOW, eds. Fish energetics. New perspectives. London: Croom Helm, pp. 155-184.

TIBALDI, E., BERALDO, P., VOLPELLI, L.A. and PINOSA, M., 1996. Growth response of juvenile dentex (Dentex dentex L.) to varying protein level and protein to lipid ratio in practical diets. Aquaculture (Amsterdam, Netherlands), vol. 139, no. 1-2, pp. 91-99. http://dx.doi.org/10.1016/0044-8486(95)01150-1.

VALDEBENITO, I. and VEGA, R., 2003. Reproductores y producción de ovas de puyes. In: J. BARILE, ed. Antecedentes para el cultivo del puye Galaxias maculatus (Pisces: Galaxiidae). Temuco, Chile: Editorial Graficasur Ltda., pp. 144.

VEGA, R., DANTAGNAN, P., MARDONES, A., VALDEBENITO, I., ZAMORANO, J. and ENCINA, F., 2013. Bases biológicas para el cultivo del puye Galaxias maculatus (Jenyns, 1842): una revisión. Latin American Journal of Aquatic Research, vol. 41, no. 3, pp. 369-386.

VERGARA, J.M., FERNÁNDEZ-PALACIOS, H., ROBAINÀ, L., JAUNCEY, K., HIGUERA, M.D.L. and IZQUIERDO, M., 1996b. The effects of varying dietary protein level on the growth feed efficiency, protein utilization and body composition of gilthead sea bream fry. Fisheries Science, vol. 62, no. 4, pp. 620-623. http://dx.doi. org/10.2331/fishsci.62.620.

VERGARA, J.M., LÓPEZ-CALERO, G., ROBAINA, L., CABALLERO, M.J., MONTERO, D., IZQUIERDO, M.S. and AKSNES, A., 1999. Growth, feed utilization and body lipid content of gilthead seabream (Sparus aurata) fed increasing lipid levels and fish meals of different quality. Aquaculture (Amsterdam, Netherlands), vol. 179, no. 1-4, pp. 35-44. http://dx.doi.org/10.1016/S00448486(99)00150-7.

VERGARA, J.M., ROBAINÀ, L., IZQUIERDO, M. and HIGUERA, M.D.L., 1996a. Protein sparing effect of lipids in diets for fingerlings of gilthead seabream. Fisheries Science, vol. 62, no. 4, pp. 624-628. http://dx.doi.org/10.2331/fishsci.62.624.

WANDSVIK, A. and JOBLING, M., 1982. Observations on growth rates of Arctic charr, Salvelinus alpinus (L) reared at low temperature. Journal of Fish Biology, vol. 20, no. 6, pp. 689-699. http://dx.doi. org/10.1111/j.1095-8649.1982.tb03979.X.

WANG, J.T., JIANG, Y.D., LI, X.Y., HAN, T., YANG, Y.X., HU, S.X. and YANG, M., 2016. Dietary protein requirement of juvenile red spotted grouper (Epinephelus akaara). Aquaculture (Amsterdam, Netherlands), vol. 450, pp. 289-294. http://dx.doi.org/10.1016/j. aquaculture.2015.08.007.

WATANABE, T., ITOH, A., SATOH, S., KITAJIMA, C. and FUJITA, S., 1985. Effect of dietary protein levels on chemical components of eggs produced by red seabream broodstock. Nippon Suisan Gakkaishi, vol.51, no. 9, pp. 1501-1509. http://dx.doi.org/10.2331/ suisan.51.1501.

WEATHERUP, R.N., MCCRACKEN, K.J., FOY, R., RICE, D., MCKENDRY, J., MAIRS, R.J. and HOEY, R., 1997. The effects of dietary fat content on performance and body composition of farmed rainbow trout Oncorhynchus mykiss. Aquaculture (Amsterdam, Netherlands), vol. 151, no. 1-4, pp. 173-184. http://dx.doi.org/10.1016/S00448486(96)01507-4.

WINDHAM, W.R., 1995. Animal feed. In: AOAC International. Official methods of analysis of AOAC International (pp. 1-27). Virginia: AOAC International.

XU, G.F., WANG, Y.Y., HAN, Y., LIU, Y., YANG, Y.H., YU, S.L. and MOU, Z.B., 2015. Growth, feed utilization and body composition of juvenile Manchurian trout, Brachymystax lenok (Pallas) fed different dietary protein and lipid levels. Aquaculture Nutrition, vol. 21, no. 3, pp. 332-340. http://dx.doi.org/10.1111/anu.12165.

ZAR, J.H., 1984. Biostatistical analysis. 2nd ed. Englewood Cliffs: Prentice-Hall Inc., pp. 718. 